\title{
Drivers for coping with flood hazards: Beyond the analysis of single cases
}

\begin{tabular}{|c|c|}
\hline $\begin{array}{l}\text { Authors: } \\
\text { Roland A. Balg } \\
\text { Henry N. Bang } \\
\text { Salliana A. For }\end{array}$ & 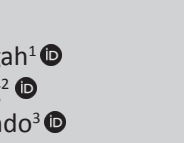 \\
\hline $\begin{array}{l}\text { Affiliations: } \\
{ }^{1} \text { College of Tec } \\
\text { University of } \\
\text { Bamenda, Can }\end{array}$ & $\begin{array}{l}\text { hnology, } \\
\text { amenda, } \\
\text { neroon }\end{array}$ \\
\hline $\begin{array}{l}{ }^{2} \text { Disaster Man } \\
\text { Centre, Bourn } \\
\text { University, Do } \\
\text { United Kingdo }\end{array}$ & $\begin{array}{l}\text { agement } \\
\text { emouth } \\
\text { sset, } \\
\text { m }\end{array}$ \\
\hline $\begin{array}{l}{ }^{3} \text { School of Life } \\
\text { Technical Univ } \\
\text { Munich, Muni }\end{array}$ & $\begin{array}{l}\text { Sciences, } \\
\text { ersity of } \\
\text { ch, Germany }\end{array}$ \\
\hline $\begin{array}{l}\text { Corresponding } \\
\text { Roland Balgah } \\
\text { balgahroland }\end{array}$ & $\begin{array}{l}\text { g author: } \\
\text { ggmail.com }\end{array}$ \\
\hline $\begin{array}{l}\text { Dates: } \\
\text { Received: } 26 \mathrm{~N} \\
\text { Accepted: } 16 \\
\text { Published: } 09\end{array}$ & $\begin{array}{l}\text { May } 2018 \\
\text { Aug. } 2018 \\
\text { Apr. } 2019\end{array}$ \\
\hline $\begin{array}{l}\text { How to cite th } \\
\text { Balgah, R.A., B } \\
\text { Fondo, S.A., 2C } \\
\text { coping with flc } \\
\text { Beyond the an } \\
\text { cases', Jàmbá: } \\
\text { Disaster Risk S } \\
\text { a678. https://c } \\
\text { 10.4102/jamb }\end{array}$ & $\begin{array}{l}\text { is article: } \\
\text { ang, H.N. \& } \\
19, \text { 'Drivers for } \\
\text { od hazards: } \\
\text { lalysis of single } \\
\text { Journal of } \\
\text { tudies 11(1), } \\
\text { doi.org/ } \\
\text { a.v11i1.678 }\end{array}$ \\
\hline $\begin{array}{l}\text { Copyright: } \\
\text { (c) 2019. The A } \\
\text { Licensee: AOS } \\
\text { is licensed und } \\
\text { Creative Comn } \\
\text { Attribution Lic }\end{array}$ & $\begin{array}{l}\text { uthors. } \\
\text { IS. This work } \\
\text { ler the } \\
\text { nons } \\
\text { ense. }\end{array}$ \\
\hline Read online: & \\
\hline 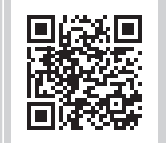 & $\begin{array}{l}\text { Scan this QR } \\
\text { code with your } \\
\text { smart phone or } \\
\text { mobile device } \\
\text { to read online. }\end{array}$ \\
\hline
\end{tabular}

Authors:

Affiliations:

${ }^{1}$ College of Technolog

University of Bamenda,

${ }^{2}$ Disaster Management

Centre, Bournemouth

University, Dorset,

${ }^{3}$ School of Life Sciences, Technical University of

Corresponding author: Roland Balgah,

Dates:

Accepted: 16 Aug. 2018

How to cite this article: Balgah, R.A., Bang, H.N. \&

Fondo, S.A., 2019, 'Drivers fo coping with flood hazards: cases', Jàmbá: Journal of Disaster Risk Studies 11(1) a678. https://doi.org/

Copyright:

Licensee: AOSIS. This work

is licensed under the

Creative Commons

Attribution License.
Flood risks continue to pose serious threats to developing countries with dire ramifications for livelihoods. Yet, contemporary research on determinants for coping with flood hazards is driven mostly by individual cases with less effort to systematically identify coping strategies across multiple floods. This research analyses potential determinants of coping strategies to flooding across multiple floods using two case studies in Cameroon. Via empirical research and qualitative or descriptive statistical analysis, the research investigated how human, social, and economic or financial variables influence household coping decisions across the two flood sites. Results suggest a great influence of social and human capital on household decisions to adopt specific coping strategies and that over $80 \%$ of flood victims in both study sites applied post-flood informal coping strategies. Analysis also shows significant inconsistencies with human capital variables, which reveal that coping determinants can be quite different even for floods occurring in the same agroecological zone. The findings also reveal that economic and financial capital has little influence on flood victims' coping decisions, contrary to popular contentions in the literature. The results of this study have implications for research and policy implementation on flood-induced coping strategies in developing countries.

Keywords: disaster risk management; natural hazards; multiple cases; coping strategies; floods; local development.

\section{Introduction}

The consequences of upsurging natural hazards and disasters are now a terrifying reality with dire ramifications for natural, social, human, financial and physical capital. Yet, managing their impacts remains one of the greatest contemporary challenges in flood-prone countries. Natural hazards took away 1.2 million lives over the decade between 2002 and 2012, affecting 268 million people and causing economic damages worth $\$ 1.7$ trillion (UNISDR 2015). Indeed, the number of people affected by natural disasters worldwide is on the rise with annual economic losses between \$250 million and \$300 million (UNISDR 2015; World Disaster Report 2015). In 2016, global natural disasters caused economic losses of US\$ 210 billion - 21\% above the 16-year average of $\$ 174$ billion. Flooding, earthquakes and severe weather were the topmost hazards, which together, produced $70 \%$ of the economic losses in 2016 (Aon 2017).

Worst still, natural disasters are having a serious toll on the world's poorest people, exacerbated by increasing hazard complexity. In view of the increasing fatalities and economic costs of natural hazards and disasters, the need for reducing hazard risks and enhancing appropriate coping and resilience strategies cannot be overemphasised (Serre et al. 2016). Therefore, the implementation of effective disaster management strategies is vital to governments if they have to achieve the Sustainable Development Goals (Clark 2015). This is even more crucial for many developing countries, where state and market institutions for effective disaster management (such as disaster relief and insurance schemes, respectively) are often missing or only exist suboptimally (Edoun, Balgah \& Mbohwa 2015). In such countries, efforts towards achieving the Sustainable Development Goals can be quickly wiped out by natural hazards and disasters. Curbing such losses will enhance sustainable development in such countries.

One limitation in the management of hazards and disasters in developing countries is the frequent absence of early warning or preventive systems, including mitigation, coping, adaptation and resilient measures. Furthermore, institutions for hazard management in many developing countries are very weak (Balgah et al. 2016; Bang 2014). Consequently, large parts of Africa and Asia will continue to experience pervasive devastation from increasing frequency of hazardous events, further impeding economic growth in these continents (Edoun et al. 2015). Reversing such negative paradigms requires an understanding of vulnerabilities and impediments to victims' 


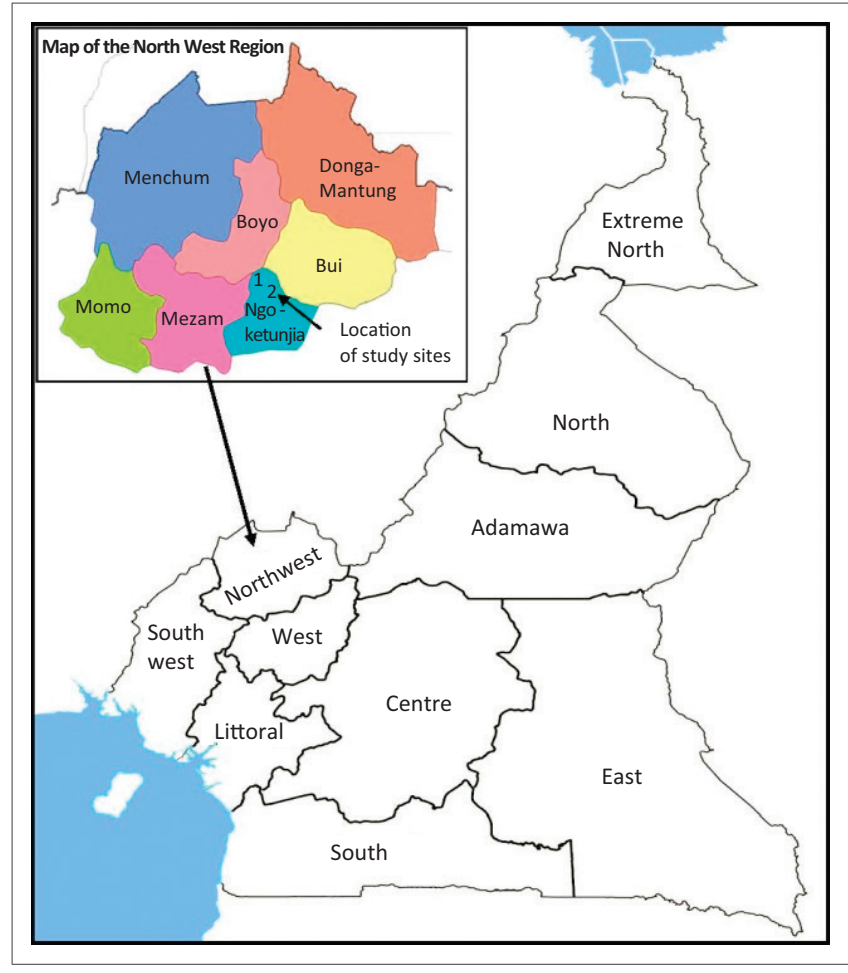

FIGURE 1: Cameroon map showing the study sites (1 - Babessi-Flood I; 2 - Baba I-Flood II) in Ngoketunjia division of the Northwest Region.

coping strategies to climate-related hazards, including identifying determinants that are robust across space and time (Berman, Quinn \& Paavola 2014; Speight, Hall \& Kilsby 2017). This paper contributes in this direction, by examining the drivers for coping decisions for two separate floods in Cameroon (see Figure 1).

The next section concisely revisits the natural hazards literature, emphasising the key role of floods. Section two has a succinct overview of the determinants for household coping decisions based on single case studies. Section three presents the materials and methods implored in the empirical examples. Empirical results are presented and discussed in section four before concluding the paper.

\section{Literature review}

\section{Natural hazards: Generalities}

The global frequency and severity of natural hazards is causing great economic losses, socio-political instability and increasing vulnerability to poverty whilst manmade hazardous events are exacerbating the effects of these hazards. Moreover, there is considerable uncertainty on current and future natural hazard trends. However, predictive modelling suggests that future occurrence of natural hazards will generally result from climate oscillations (IPCC 2014).

Hydro-meteorological hazards, mainly droughts and floods, account for almost $90 \%$ of global natural hazards (IPCC 2014). The bulk of the estimated total economic loss of US\$3.8 trillion from natural hazards in the next few decades will emanate from developing countries and $75 \%$ of all economic losses and over $60 \%$ of total lives lost will continuously affect Africa, particularly sub-Saharan African (SSA) countries where poverty is pervasive (World Bank 2014a). These grave consequences will be further compounded by high levels of exclusion, vulnerability and limited government hazard management capacities (Bang, Miles \& Gordon 2017; Edoun et al. 2015).

Floods are the most important global form of natural hazards in contemporary Africa and accounted for almost $83 \%$ of all disasters in Africa in 2010, causing an economic loss of $\$ 59.2$ million in the same year (Guha-Sapir, Hoyois \& Below 2013; Ozger 2017). In addition, this situation is set to worsen with climate change (IPCC 2014). Indeed, climaterelated disasters that cause flooding are on the rise worldwide and accounted for $87 \%$ of natural disasters in 2014, continuing a 20-year-long trend of climate-related disasters (World Disaster Report 2015).

Currently, increasing flood frequency affects assets, entitlements and livelihood security especially for the poor in hazard-affected Africa (Mbereko, Chimbari \& Mukaratirwa 2018; Ngwa et al. 2015). The direct effects include forceful displacement, destruction of houses and fixed assets, increased disease prevalence and loss of human lives (Buchenrieder, Mack \& Balgah 2017; Dube, Mtapuri \& Matunhu 2018; Ntungwe 2015). However, the victims are not always passive in the face of such events. Often, they may apply either adaptive or coping strategies. Whilst adaptive strategies aim at minimising flood risks, coping strategies are employed to deal with the aftermaths (Serre et al. 2016).

Often, hazard victims prefer preventive strategies, but have no option than to adapt in their absence (Berman et al. 2014). Some adaptive and coping measures employ formal and informal instruments. Informal instruments include individual, household or community-based actions whilst formal instruments are mainly market and public interventions. Examples of informal pre-hazard instruments include crop diversification, off-farm employment, informal credit and insurance arrangements, creating buffer stocks or adhering to risk-sharing networks (Fafchamps \& Lund 2003:210). Informal post-hazard strategies include buying and selling of real assets, informal borrowing, asset liquidation and consumption smoothing. A common and widely known example of a formal pre-hazard instrument is an insurance premium. Some formal post-hazard instruments include disaster relief, government or non-governmental organisations' (NGO) support, social capital or networks community assistance, saving and food stocks and sales of personal assets or livestock if not destroyed (Abid, Schneider \& Scheffran 2015; Buchenrieder et al. 2017; Holzmann 2001; Mbereko et al. 2018).

The need to understand how victims make these decisions prior to, during or after natural hazards and under what circumstances they would prefer some actions over others is crucial in enhancing long-term prevention, reduction, coping, 
adaptation as well as for building resilience in hazard-prone communities. Clearly, this is a herculean task for any one piece of scientific work. With this understanding, this paper makes a modest contribution by analysing the determinants for adopting specific coping strategies by hazard victims, based on two case study floods in Cameroon. This hinges on the contention that determinants, which are robust across space and time, are likely to have stronger policy implications than those identified in single, isolated case studies.

\section{Flood hazards: A succinct overview of relevance and impacts}

Flooding is one of the Earth's most common, most destructive and most deadly natural hazards and flood damages continue to rise worldwide with dire consequences for natural, social, physical, financial and human capital (Bang et al. 2017). Over $50 \%$ of all disasters recorded in 2010, for instance, were of floods origin, representing an increase of over 145\%, compared to the mean between 2000 and 2009. In the same year, floods inflicted harm to an estimated 2.6 billion people worldwide, leaving behind direct and indirect economic losses of about $\$ 46.9 \mathrm{bn}$ (Guha-Sapir et al. 2013). Contemporary flood impacts have serious direct and indirect social, psychological and economic effects on victims - destruction of property, loss of lives and displacement, reduced human dignity, posttraumatic psychological and mental disorders, and increased frequency of diseases (Bang et al. 2017; Ntungwe 2015). Flood effects are often more severe on the very poor in developing countries, mainly because of weak disaster management systems (Bang 2014) and rampant state and market failures to contain flood aftermaths (Ntungwe 2015). Understanding drivers for coping with flood hazards can stimulate flood impact, reducing policy options of relevance across many developing countries.

\section{Determinants for coping with flood hazards}

Flood victims often engage in strategies that can best support them cope with the aftermaths. In developing countries, informal coping strategies are more common because state and market mechanisms are often absent, dysfunctional or unreliable (Berman et al. 2014; Edoun et al. 2015; Holzmann 2001). Nevertheless, when these mechanisms are present, victims would not hesitate to appropriate them, often combining the formal with informal instruments (Balgah, Buchenrieder \& Mbue 2012; Balgah, Buchenrieder \& Zeller 2015).

Research evidence suggests that socio-economic factors fundamentally determine victims' decisions to adopt specific flood-coping strategies. Berman et al. (2014), for instance, found out that age, education and household wealth crucially influenced the coping choices for flood victims in Uganda. Older households relied more on social support than younger ones, whilst the more educated households relied largely on own savings to buffer flood effects. However, Boamah et al. (2015) report mixed results in their cross-sectional survey amongst flood victims in Tanzania and Nigeria. Similar to Berman et al. (2014), age and access to economic resources were found to influence the type of coping strategies adopted by victims in Nigeria. This was not the case in Tanzania, where other factors were more important. This inconsistency is probably because of context-specific factors, which were not captured in the research.

Key drivers for coping decisions identified in topical literature include social capital abundance and economic activities (Armah et al. 2010; Balgah et al. 2015; Fafchamps \& Lund 2003; Jakiela \& Ozier 2012); access to alternative natural resources (Berman et al. 2014; Cervantes-Godoy, Kimura \& Anton 2013); past experiences (Boamah et al. 2015; Mbereko et al. 2018); gender and occupation of the household head (Balgah et al. 2016; Mobarak et al. 2012); poverty levels, risk exposure and access to economic resources (Bryan, Chowdhury \& Mobarak 2011; Cervantes-Godoy et al. 2013; Holzmann 2001; Meredith et al. 2013); information (a) symmetry (Jensen 2012); risk perceptions, culture and beliefs (Balgah et al. 2015; Wachinger et al. 2013); and the functioning levels of state and market hazard management institutions (Cervantes-Godoy et al. 2013; Holzmann 2001).

For instance, Meredith et al. (2013) reveal that liquidity constraints and high prices negatively affected coping decisions amongst hazard victims in Kenya. Similar findings in Cameroon reveal that very limited finances prevent victims from easily coping and adapting to flood hazards (Ngondjeb 2013). Similarly, Bryan et al. (2011) in a more restricted study demonstrated that access to improved agricultural techniques, educational levels and information asymmetry strongly influenced household flood-coping choices in Bangladesh. Balgah et al. (2015) report the unwillingness of flood victims in rural Cameroon to move to new havens, as existing cultural and belief systems restrict them from living far away from the graves of their beloved ones. Dube et al. (2018) in a broader sense relate poverty to flood risk management in Zimbabwe.

Contemporary research on household coping decisions to floods generally contends that coping decisions are spatially ubiquitous. With the exception of a few studies (see Berman et al. 2014; Boamah et al. 2015; Ozger 2017), knowledge on coping with flood hazards is largely contingent on crosssectional, individual case-specific studies. Analysing multiple case studies will arguably identify determinants, which are robust over space and time (Speight et al. 2017). Such determinants imbibe greater potentials for policy. This paper embraces this philosophy by analysing two floods cases from Cameroon.

\section{Materials and methods Background of the study area}

This study was done in Cameroon, one of the SSA countries highly affected by floods. Its Northwest Region (see Figure 1), the third most populated region in the country (over 1.8 million), has increasingly witnessed flood episodes especially in the last decade, mainly as a consequence of 
climate variability (Innocent, Bitondo \& Balgah 2016). These floods have dire consequences for the predominantly agricultural populations in the region. Indeed, over $75 \%$ of the population in Northwest Cameroon depends on subsistence, rain-fed agriculture for their livelihoods (Yengoh 2012). Besides, the poverty rate in the region, estimated at $51 \%$, represents $13 \%$ of the total poor in the country (Ambagna, Kane \& Oyekale 2012). Two seasons dominate the region, namely the rainy season, spanning from mid-March to the end of October, and the dry season, from November to mid-March (Innocent et al. 2016).

The study area hosts two communities (Babessi and Baba I), located in Ngoketunjia, one of the seven divisions that make up the Northwest Region of Cameroon (see Figure 1), which has been struck in recent years by two independent devastating floods:(1) The Babessi floods of September 09, 2012, (hereafter also called Flood I). This flood resulted in the displacement of 4000 inhabitants from 50 families and complete destruction of 26 homes (Loh 2012). In addition, victims lost over $60 \%$ of their livestock and almost $100 \%$ of cash held in the household at the time of the floods. Food crops and agricultural lands were greatly damaged, and food consumption at household level dropped from a mean of three to two meals per day, pre- and post-floods, respectively (Balgah et al. 2015). (2) The Baba I flood of September 14, 2015 (hereafter also called Flood II). Baba I is a neighbouring community to Babessi. This flood left around 100 people from 65 families homeless, completely submerging 35 homes and causing enormous economic, agricultural and psychosocial damages in the community (Bruno 2015). Households were reported to have adopted predominantly informal coping strategies such as relying on family support and community solidarity to initially deal with the immediate floods aftermaths (Balgah et al. $2015,2016)$. We use these two case study floods to analyse the drivers for household decisions to predominantly adopt informal coping strategies in both floods. A number of factors make this comparison interesting. Firstly, Babessi is host to all of the administrative units under the Babessi Council area. As such, it is more cosmopolitan than Baba I, which is typically rural. Secondly, most of those affected in these two research sites depend on agriculture for their livelihoods (Balgah et al. 2015). However, because of the urban nature of Babessi, it tends to depend on Baba I for a substantial supply of food. Thirdly, there is a 3-year window between the two floods, which could have induced experiential knowledge sharing and disaster preparedness. A key interest here is to identify drivers that are robust over space and time of more relevance to policy than is obtainable from isolated cross-sectional case studies currently dominating the floods literature.

\section{Methodology and sampling approaches}

The choice of the case studies is logically justified from at least four fronts. Firstly, developing countries are hypothesised to be most exposed to the current and future effects of floods (Edoun et al. 2015; IPCC 2014). Therefore, it is important to draw empirical examples from these countries for analysis, where results will be highly relevant for policy. Secondly, floods are amongst the most frequent type of natural shocks worldwide (Guha- Sapir et al.2013; OECD 2016). Researching on floods would therefore have implications beyond Cameroon, from which the case studies are drawn. Thirdly, Cameroon is one of the countries in SSA greatly affected by floods (Bang et al. 2017; Ngwa et al. 2015). Drawing case studies from this country can potentially have policy implications. Fourthly, although the two case study floods analysed here occurred in different years, they share some similarities, namely, that (1) they are both in the same agroecological zone in Cameroon and (2) the floods occurred in the same month of the year (September). Such a choice minimises the effects of extraneous variables that cannot be accounted for by their search. In addition, the research team had previously collected data on Flood I. This enhanced motivation and created a window of opportunity to apply the same research approach and instruments for Flood I to the Flood II case study, allowing for comparative analysis.

\section{Data collection and analysis}

The data analysed here was collected only from flood victims. Sampling was done at the household level. A structured questionnaire modified following Grotaert et al. (2004) and Zeller et al. (2006) was used in both surveys to allow for comparability. Trained enumerators in both cases collected data less than 2 months after the floods in order to deliberately reduce data unreliability that was likely to accompany long recall periods. Interview and data recording took place at the homestead of the interviewees, allowing the research team to observe some of the effects mentioned during the interview. Seventythree victims ( 38 out of 56 for Flood I and 35 out of 65 in Flood II, respectively) representing almost $61 \%$ of all the victims participated in the survey. Victims who were not sampled simply refused to participate in the survey or were not in the communities at the time of the survey. Observations and key informant interviews complemented the survey. Collected data were entered and analysed using SPSS (Statistical Package for Social Sciences), version 20.0 , and results were validated at $95 \%$ confidence interval $(\alpha=0.05)$. Logistic regressions were performed to identify key drivers for household coping decisions in the two case study floods. Results of the analysis are presented and discussed in the next section.

\section{Results and discussion Descriptive socio-economic characterisation of the sample}

Most flood victims in our case studies have only primary school education $(71.8 \%$ in Flood I and $60 \%$ in Flood II, respectively), with almost $70 \%$ of the entire sample largely depending on subsistence agriculture for their livelihoods. Furthermore, most victims are married and living together with their spouses (about $77 \%$ for Flood I and $80 \%$ for Flood II). Table 1 has additional descriptive statistics. 
TABLE 1: Descriptive statistics of the sampled households by flood incidence.

\begin{tabular}{llcccc}
\hline Variable & Village & Minimum & Maximum & Mean & $\begin{array}{c}\text { Standard } \\
\text { deviation }\end{array}$ \\
\hline Age of household head & Flood I & 23 & 82 & 42.64 & 13.66 \\
& Flood II & 22 & 75 & 43.51 & 12.60 \\
Household size & Flood I & 1 & 26 & 7.82 & 5.13 \\
& Flood II & 1 & 22 & 8.14 & 4.00 \\
$\begin{array}{l}\text { Annual expenditures } \\
\begin{array}{l}\text { on clothing and } \\
\text { footwear (FCFA) }\end{array}\end{array}$ Flood I & 30000 & 600000 & 198690 & 150100 \\
$\begin{array}{l}\text { Number of groups to } \\
\text { which a member of the } \\
\text { household belong }\end{array}$ & Flood II & 5000 & 250000 & 78380 & 68850 \\
\hline
\end{tabular}

Note: Currency values have been rounded up to the nearest existing value; 1 US\$ $\approx$ FCFA 600 . FCFA, Franc de la Communauté Financière d'Afrique.

The mean sample age of victims ( $\approx 43$ years) suggests that most victims are still very active. This mean is lower than the life expectancy of 57 years in Cameroon (World Bank 2014 b). The mean sample household size $(\approx 8)$ mirrors other research findings reported for other rural areas in the region (e.g. Ngwa et al. 2015). Large household sizes suggest the importance that flood victims may attach to family labour, a key input in subsistence-based agricultural systems. Such contentions have been raised in previous research works in rural Cameroon (Balgah et al. 2016). The mean annual household expenditure on clothing and footwear for the entire sample of FCFA (Franc de la Communauté Financière d'Afrique) $138535(\approx$ 230.00) may be indicative of the importance of dressing in the communities. These expenditures for Flood I victims more than double that of Flood II victims (FCFA 198690 $[\approx \$ 330.00]$ and FCFA $78380[\approx \$ 130.00]$, respectively). A possible explanation for this large difference is the fact that Flood I (Babessi) is the seat of the local Council. Households probably have social pressure from nonindigenes to spend more on dressing than in the Flood II (Baba I) community. However, from a hazard management perspective, such expenditures absorb income that could have been available for possible investment in ex ante or ex post-hazard management strategies and demonstrates a likely preference, for instance, for leisure over formal insurance. This conjecture is corroborated by the fact that no household in the two research communities had a flood insurance policy. It is also likely that expenses on clothing and footwear were necessary to command social respect in the community. Further research will be needed to make conclusive statements.

In general, over $80 \%$ of all sampled flood victims $\approx \approx 90 \%$ of Flood I and $\approx 80 \%$ of Flood II) belonged to a group or network. This is shown in Figure 2. However, Flood I households belonged to one more group and/or network as compared to their Flood II counterparts. In addition, $28.6 \%$ and $46.2 \%$ of the victims from Flood I and II, respectively, reported holding leadership positions in at least one of the groups or networks they belonged to (see Figure 3). These statistics suggest the abundance of social capital, its potential role in hazard coping and its possible influence on household decisions to adopt specific coping strategies after the floods, especially under prevailing conditions of state and market failure. Such

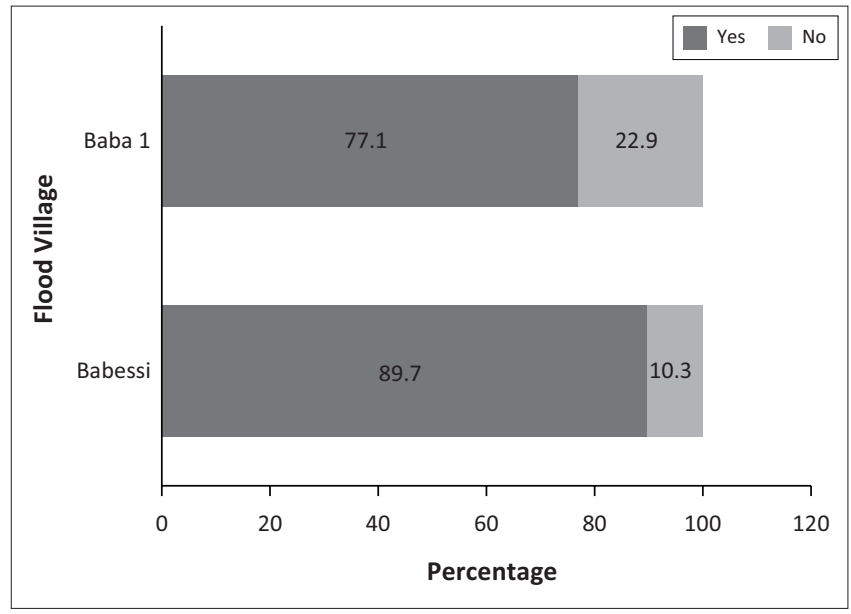

FIGURE 2: Household membership in groups and/or networks.

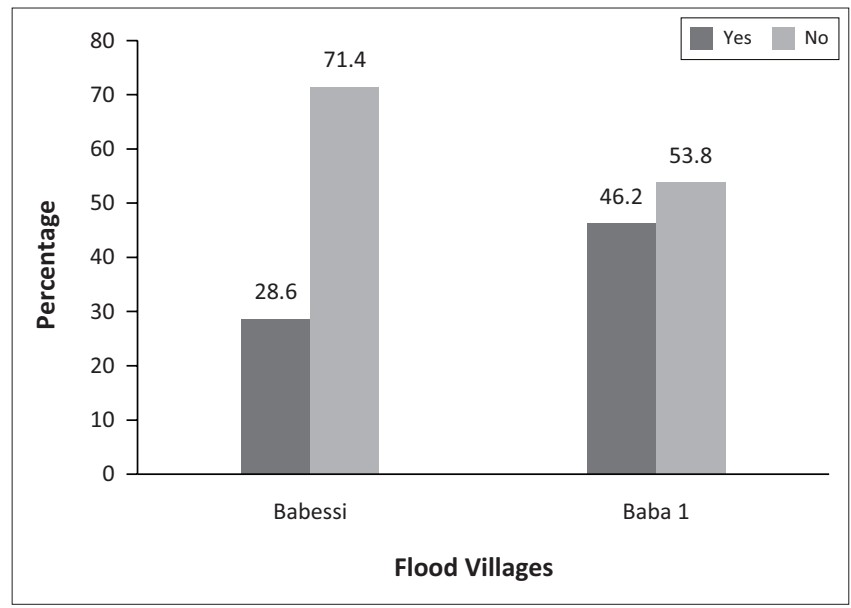

FIGURE 3: Households with leadership positions in groups or networks.

contentions have been previously emphasised (Armah et al. 2010; Bastagli \& Holmes 2014; Jakiela \& Ozier 2012).

\section{Determinants for adopting informal coping strategies}

Descriptive statistics revealed that in general, over $80 \%$ of all floods victims applied only informal strategies to cope with the aftermaths of both floods whilst $20 \%$ employed a combination of formal and informal instruments to cope with the floods. No household applied solely formal (state and market) coping strategies. Therefore, we attempt to examine which factors were responsible for such biased coping choices observed in two independent floods. Binary logistic regressions were performed to assess the influence of different variables on the households' decision to predominantly adopt informal coping mechanisms in both case study floods. For a better apprehension, the variables were grouped into human, social and financial or economic capital determinants for the analysis. The grouped variables were separately regressed against a binary variable, namely the household decision to predominantly adopt informal coping strategies after two independent floods. The binary variable was represented as 1, when the household's coping strategy was informal and 0 when it was not. 
The regression model can therefore be represented as:

$$
Y=\alpha+\beta_{1} X_{1}+\beta_{2} X_{2}+\ldots+\beta n X n+\mathrm{e}
$$

where:

$Y$ is a binary variable $(1,0)$, indicating the coping decision of the household,

$\alpha$ is the constant,

$\beta$ s the predictors,

$X 1-X \mathrm{n}$ are the independent variables influencing the adoption decisions, and e is the error term.

Before doing the analysis by form of capital, the independent variables were grouped and used to establish the goodness-of-fit for each case study flood. Table 2 presents the model output. The results indicate that the independent variables acceptably explain the decision to adopt mainly informal coping strategies in Flood I $\left(X^{2} \leq 0.05\right)$ and not necessarily with the same vigour in Flood II $\left(X^{2} \geq 0.05\right)$. As evident from Table 3, almost 52\% of the decision to adopt informal coping strategies is explained by the selected variables in Flood I. However, the variables in Flood II account for only slightly above $25 \%$ of the decision-making process. Probably, a different set of variables would be needed to convincingly explain the choice of decisions in Flood II. This discrepancy suggests that different variable sets can influence the decision to adopt specific risk-coping strategies even for floods that occur in the same agroecological zone. It is also possible that the combination of different (formal and informal) coping strategies that was not considered separately could be responsible for lowered model performance. However, for the sake of consistency, we had to compare the same variables across the two case study floods. Nevertheless, we generally acknowledge that additional variables other than those tested in our case study would be needed to better explain the decisions in the second case study flood. This of course would require further research.

Furthermore, we examined the robustness of similar important determinants in influencing coping strategies for both floods. In our opinion, the robustness of variables across

TABLE 2: Omnibus tests of model coefficients.

\begin{tabular}{llccc}
\hline Regression type & Village & Chi-square & df & Sig. \\
\hline Step & Flood I & 15.680 & 8 & 0.05 \\
& Flood II & 5.780 & 8 & 0.67 \\
Block & Flood I & 15.680 & 8 & 0.05 \\
& Flood II & 5.780 & 8 & 0.67 \\
\multirow{2}{*}{ Model } & Flood I & 15.680 & 8 & 0.05 \\
& Flood II & 5.780 & 8 & 0.67 \\
\hline
\end{tabular}

df, degrees of freedom; Sig., significance.

TABLE 3: Model summary.

\begin{tabular}{lccc}
\hline Community & -2 Log likelihood & Cox \& Snell $\boldsymbol{R}$ square & Nagelkerke $\boldsymbol{R}$ square \\
\hline Flood I & 23.899 & 0.33 & 0.52 \\
Flood II & 26.290 & 0.15 & 0.25 \\
\hline
\end{tabular}

Note: Estimation was terminated at iteration number 7, as parameter estimates changed by less than 0.001 . case studies will provide support for their consideration in flood-related policy prescriptions of wider (national or regional) relevance.

\section{Human capital}

Regression results for human capital variables are presented in Table 4. Human capital variables largely influenced coping decisions in the two flood case studies differently. With the exception of household size, all the other variables positively influenced the coping decisions of Flood I victims, as observed from the beta values. These results support existing contentions from independent, cross-sectional studies (Balgah et al. 2016; Jensen 2012; Mobarak et al. 2012). However, the exact opposite effect was observed in Flood II. As mentioned earlier, the variables tested in Flood II explain only $25 \%$ of the flood-coping decisions. This in effect means that there are other important determinants, which were not captured in our research. Further research will be necessary to provide better explanations to these observations. Nevertheless, such results draw our attention to the fact that coping determinants can be quite different even for floods occurring in the same agroecological zone. As suggested by Boamah et al. (2015), whilst an individual case study approach is useful, solid trends on which broad-based (flood) policies can depend will only emerge from the analysis of multiple cases across space and time.

\section{Social capital}

Table 5 presents the results of the regression analysis on social capital variables. Marital status and membership in groups or networks positively influenced Flood I victims to mainly adopt informal coping strategies, with the latter being significant at the 5\% level $(p=0.009)$. With the exception of leadership positions held in groups and

TABLE 4: Human capital variables.

\begin{tabular}{llcccccc}
\hline Variable & Village & $\boldsymbol{\beta}$ & S.E. & Wald & Df & Sig. & $\operatorname{Exp}(\boldsymbol{\beta})$ \\
\hline Age & Flood I & 0.080 & 0.076 & 1.099 & 1 & 0.30 & 1.083 \\
& Flood II & -0.033 & 0.064 & 0.262 & 1 & 0.61 & 0.968 \\
Education & Flood I & 0.464 & 0.495 & 0.879 & 1 & 0.35 & 1.591 \\
& Flood II & -1.082 & 0.744 & 2.118 & 1 & 0.15 & 0.339 \\
Household size & Flood I & -0.024 & 0.159 & 0.022 & 1 & 0.88 & 0.977 \\
& Flood II & -0.150 & 0.162 & 0.860 & 1 & 0.35 & 0.860 \\
Main occupation of & Flood I & 2.900 & 1.850 & 2.457 & 1 & 0.12 & 18.171 \\
household head & Flood II & -0.010 & 1.111 & 0.000 & 1 & 0.99 & 0.990 \\
\hline
\end{tabular}

$\beta$, beta value; S.E., standard error; $\mathrm{df}$, degrees of freedom; Wald, Wald test of true parameter value; $\operatorname{Exp}(\beta)$, expected beta value; Sig., significance.

TABLE 5: The level to which social capital variables influence coping strategies by floods.

\begin{tabular}{lllrllll}
\hline Variable & Community & $\boldsymbol{\beta}$ & S.E. & Wald & df & Sig. & $\operatorname{Exp}(\boldsymbol{\beta})$ \\
\hline Marital status & Flood I & 3.142 & 1.635 & 3.694 & 1 & 0.050 & 23.145 \\
& Flood II & -0.299 & 0.878 & 0.116 & 1 & 0.730 & 0.742 \\
Membership in groups & Flood I & 6.557 & 2.511 & 6.821 & 1 & 0.010 & 703.990 \\
or networks & Flood II & -1.273 & 1.636 & 0.606 & 1 & 0.440 & 0.280 \\
\multirow{2}{*}{$\begin{array}{l}\text { Leadership in groups or } \\
\text { networks }\end{array}$} & Flood I & -0.921 & 1.206 & 0.583 & 1 & 0.450 & 0.398 \\
Gender & Flood II & 0.948 & 1.299 & 0.532 & 1 & 0.470 & 2.579 \\
& Flood I & -3.088 & 1.764 & 3.064 & 1 & 0.080 & 0.046 \\
& Flood II & -1.527 & 1.455 & 1.101 & 1 & 0.290 & 0.217 \\
\hline
\end{tabular}

$\beta$, beta value; S.E., standard error; $\mathrm{df}$, degrees of freedom; Wald, Wald test of true parameter value; $\operatorname{Exp}(\beta)$, expected beta value; Sig., significance. 
networks (and the above mentioned), all other tested social capital variables had negative values in both case study floods. Belonging to a group or network did not automatically translate into benefiting from these networks after the floods, as generally conjectured in the topical literature (Grotaert et al. 2004). This suggests that the type of groups and networks matter. It had to take leadership and therefore additional influence in these networks, for instance, for Flood I victims to benefit from the abundance of social capital captured through membership in networks. Even the gender of the household head did not demonstrate a positive influence on the coping decisions in both case studies, suggesting that female-headed households were more likely to adopt informal coping strategies than male-headed ones. The results generally deviate from contemporary positions in the topical state of the art on the relevance of social capital for risk-coping in developing countries (Armah et al. 2010; Balgah et al. 2016; Bastagli \& Holmes 2014; Jakiela \& Ozier 2012; Mobarak et al. 2012). However, they reiterates the fact that the type of social capital is crucial for it to significantly influence coping decisions of flood victims. However, further research is required to draw firmer conclusions.

\section{Financial and economic capitals}

Following Zeller et al. (2006), financial capital was captured mainly through the estimated household income at the time of the floods, whilst economic capital was computed as the total value of some selected household assets and the livestock owned by the household at the time of the floods. The summary results are presented in Table 6 . The results clearly show that economic and financial capitals had no influence on flood victims' coping decisions. These results widely deviate from the general scholarly contentions, where economic and financial capitals have been identified as key determinants for coping with natural hazards (see, for instance, Cervantes-Godoy et al. 2013; Holzmann 2001; Meredith et al. 2013). It departs even from simple logic! We explain these rather strange findings that financial and economic capitals may have been normally distributed amongst flood victims, most of whom are generally likely to be living in poverty. As such, financial and economic capitals could not have been robust enough to determine coping decisions in the research region, because households cannot be substantially differentiated based on these variables. Such contentions have been raised in recent research in the region (e.g. Balgah et al. 2016). However, further research is necessary to draw firmer conclusions.

TABLE 6: Analysis of economic and financial capital by flood type.

\begin{tabular}{llcccccc}
\hline Village & Variable & $\boldsymbol{\beta}$ & S.E. & Wald & df & Sig. & $\operatorname{Exp}(\boldsymbol{\beta})$ \\
\hline Flood I & Economic capital & 0.000 & 0.000 & 0.941 & 1 & 0.33 & 1.000 \\
& Financial capital & 0.000 & 0.000 & 0.148 & 1 & 0.70 & 1.000 \\
Flood II & Economic capital & 0.000 & 0.000 & 1.408 & 1 & 0.24 & 1.000 \\
& Financial capital & 0.000 & 0.000 & 2.527 & 1 & 0.11 & 1.000 \\
\hline
\end{tabular}

$\beta$, beta value; S.E., standard error; $\mathrm{df}$, degrees of freedom; Wald, test of true parameter value; $\operatorname{Exp}(\beta)$, expected beta value; Sig., significance.

\section{Conclusion and recommendations}

This paper has assessed the different drivers for household decisions to flood hazards, based on two case study floods in Cameroon. The objective was to identify drivers that go beyond individual, isolated case studies currently dominating the topical literature and identify potential determinants robust across multiple floods, which could be appropriated for flood hazard policy making. The study focused on two neighbouring villages (case study sites) in the Northwest Region of Cameroon that are prone to frequent flooding. Empirical research involving quantitative and qualitative data were collected and analysed from flood-affected households in the two case study floods. Descriptive statistics and regression analyses results were used to test the robustness of selected human, social, and economic or financial variables in influencing household coping decisions across the two case studies. Same variables were used for both case studies to permit comparability. The findings have revealed mixed results - human capital variables, for instance, have been found to positively affect household coping decisions in Flood I case study and not in Flood II. A differentiated relevance of social capital was also observed in both study sites. Whilst group membership and social networks were crucial for coping decision-making in Flood I, holding leadership position in these groups was more decisive in Flood II. Financial and economic capitals had no influence on coping decisions in both case studies. Overall, the tested variables explained only $52 \%$ and $25 \%$ of the total coping decisions for case study one and two, respectively. This, we assume, is partially because around $20 \%$ of all victims used a combination of informal (community-based) and formal (state led) strategies to cope with the floods. In addition, it is also possible that the initially selected variables in our model (based on the contemporary state of the art) did not include the key variables that were specifically relevant for the flood victims. However, this was necessary for comparative analysis across the two case study floods.

Given the current status quo, it seems plausible to hypothesise that flood victims in developing countries are likely to depend heavily on informal coping strategies as a result of widespread state and market failures for flood risk management. However, given the opportunity, they would appropriate formal instruments and opportunities to cope with flood hazards. In the meantime, research should continue to support policymakers by increasingly analysing multiple case studies so that trends can be identified to support policy decisions for flood risk management beyond individual case studies. A starting point could be to undertake an in-depth review of the existing literature and cautiously identify robust determinants across published case studies. This should be accompanied by increased risk reduction measures that can mitigate the impacts of floods when they occur. Perhaps, developing countries should take the prevention and preparedness for flood risks more seriously, as they stand to suffer most from increasing flood hazards, predominantly because of the failure of state and market institutions for flood hazard management. 


\section{Acknowledgements}

We acknowledge with thanks the critical comments of Prof. Dr Gertrud Buchenrieder from the Technical University of Munich on the initial draft. These comments reminded us, amongst other things, of the need to clarify the different (flood) hazard management strategies, for which coping is just one of them. The contributions of the anonymous referees who partook in the review process are also acknowledged.

\section{Competing interests}

The authors declare that they have no financial or personal relationships that may have inappropriately influenced them in writing this article.

\section{Authors' contributions}

This research has been realised with cordial collaboration between all the named authors. R.A.B. led the design of the study and did the field research including data collection, statistical analysis and the preliminary draft. H.N.B. and S.A.F. reviewed and upgraded the manuscript via literature search, more qualitative analysis and proofreading. All the authors reviewed and approved the final manuscript prior to submission.

\section{References}

Abid, M., Schneider, U. \& Scheffran, J., 2015, 'Adaptation to climate change and its impacts on food productivity and crop income: Perspective of farmers in Rural Pakistan', Journal of Rural Studies 47, 254-266. https://doi.org/10.1016/j. jrurstud.2016.08.005

Ambagna, J., Kane, G. \& Oyekale, S., 2012, 'Subsistence farming and food security in Cameroon: A macroeconomic approach', Life Science Journal 9(4), 3949-3954.

Aon, B., 2017, 2016 annual global climate and catastrophe report, viewed 12 February 2018, from http://thoughtleadership.aonbenfield.com/Documents/20170117ab-if-annual-climate-catastrophe-report.pdf.

Armah, F.A., Yawson, D.O., Yengoh, G.T., Odoi, J.O. \& Afrifa, E.K., 2010, 'Impact of floods on livelihoods and vulnerability of natural resource dependent communities in Northern Ghana', Water 2(2), 120-139. https://doi.org/10.3390/w2020120

Balgah, R.A., Buchenrieder, G. \& Mbue, I.M., 2015, 'When nature frowns: A comprehensive impact assessment of the 2012 Babessi floods on people's livelihoods in rural Cameroon', Jàmbá: Journal of Disaster Risk Studies 7(1), Art. \#197, 8 pages. https://doi.org/10.4102/jamba. v7i1.197

Balgah, R.A., Buchenrieder, G. \& Zeller, M., 2012, Dynamics of formal and informal responses to shocks. With empirical evidence from Cameroon, Lambert Academic Publishing, Saarbrücken.

Balgah, R.A., Mbue, I.N., Kimengsi, J.N. \& Ngwa, K.A., 2016, 'Factors influencing the adoption of informal mechanisms by disaster victims in Cameroon', International Journal of Social and Political Science 2(2), 6-29.

Bang, H., 2014, 'General overview of the disaster management framework in Cameroon', Disasters (38)3, 562-586. https://doi.org/10111/disa.1261

Bang, H., Miles, L. \& Gordon, R., 2017, 'The irony of flood risks in African Dryland environments: Human security in North Cameroon', World Journal of Engineering and Technology 5, 109-121. doi.org/10.4236/wjet.2017.53B013

Bastagli, F. \& Holmes, R., 2014, Delivering social protection in the aftermath of a shock. Lessons from Bangladesh, Kenya, Pakistan and Vietnam, Overseas Development Institute, London.

Berman, R.J., Quinn, C.H. \& Paavola, J., 2014, 'Identifying drivers of household coping strategies to multiple climatic hazards in Western Uganda: Implications for adapting to future climate change', Climate and Development 7(1), 71-84. https:// doi.org/10.1080/17565529.2014.902355

Boamah, S.A., Armah, F.A., Kuuire, V.Z., Ajibade, I., Luginaah, I. \& McBean, G., 2015 'Does previous experience of floods stimulate the adoption of coping strategies? Evidence from cross sectional surveys in Nigeria and Tanzania', Environment 2(4), 565-585. https://doi.org/10.3390/environments2040565

Bruno, C.A., 2015, Babessi battered by 2 floods in 3 years, viewed 15 November 2018 from http://www.thegreennews.info/babessi-battered-by-2-floods-in-3-years/.
Bryan, G., Chowdhury, S. \& Mobarak, A., 2011, Seasonal migration and risk aversion, CEPR Discussion Paper, Centre for Economic Policy Research, Development Economics, London, UK.

Buchenrieder, G., Mack, C. \& Balgah, R.A., 2017, 'Human security and the relocation of internally displaced environmental refugees in Cameroon', Refugee Survey Quarterly 36(3), 20-47. https://doi.org/10.1093/rsq/hdx005

Cervantes-Godoy, D., Kimura, S. \& Anton, J., 2013, Smallholder risk management in developing countries, OECD Food, Agriculture and Fisheries Papers 61, OECD Publishing, Paris

Clark, H., 2015, Sustainable development goals, United Nations Development Program (UNDP), 25th September 2015, viewed 27 September 2015, from http://www. undp.org/content/undp/en/home/mdgoverview/post-2015-developmentagenda/.

Dube, E., Mtapuri, O. \& Matunhu, J., 2018, 'Flooding and poverty: Two interrelated social problems impacting rural development in Tsholotsho district of Matabeleland North province in Zimbabwe', Jàmbá: Journal of Disaster Risk Studies 10(1), a455. https://doi.org/10.4102/jamba.v10i1.455

Edoun, E.I., Balgah, R.A. \& Mbohwa, C., 2015, 'The impact of effective management of natural disasters for Africa's development', Economic Research 28(1), 924-938. https://doi.org/10.1080/1331677X.2015.1087325

Fafchamps, M. \& Lund, S., 2003, 'Risk sharing networks in rural Philippines', Journal of Development Economics 72(1), 261-287. https://doi.org/10.1016/S03043878(03)00029-4

Grotaert, C., Narayan, C., Jones, V.N. \& Woolcock, M., 2004, Measuring social capital. An integrated questionnaire, World Bank Working Paper No. 18, The World Bank, Washington, DC.

Guha-Sapir, D., Hoyois, P.H. \& Below, R., 2013, Annual disaster statistical review 2013 The numbers and trends, Centre for Research on the Epidemiology of Disasters, Brussels.

Holzmann, R., 2001, Risk and vulnerability: The forward looking role of socia protection in a globalizing world, Social Protection Discussion Paper No. 0109, The World Bank, Washington, DC.

Innocent, N., Bitondo, D. \& Balgah, R., 2016, 'Climate variability and change in the Bamenda highlands of North Western Cameroon: Perceptions, impacts and coping mechanisms', British Journal of Applied Science and Technology, 12(5), 1-18. https://doi.org/10.9734/BJAST/2016/21818

IPCC, 2014, UN climate change chief Christiana Figueres! Latest IPCC findings point to extreme climate change risk, Plethora of opportunities for climate action, United Nations Climate Change Secretariat, Bonn.

Jakiela, P. \& Ozier, O., 2012, Does Africa need a rotten Kin Theorem? Experimental evidence from village economies, Policy Research Working Paper 6085, Impact Evaluation Series No. 58, The World Bank, Washington, DC.

Jensen, R., 2012, 'Do labor market opportunities affect young women's work and family decisions? Experimental evidence from India', Quarterly Journal of Economics 127, 753-792. https://doi.org/10.1093/qje/qjs002

Loh, C., 2012, 'Cameroon: Floods render 26 families homeless in Babessi', Cameroon Tribune, 14 September 2012, viewed 20 September 2012, from http:allafrica.com/ stories/21209171112.html.

Mbereko, A., Chimbari, M.J. \& Mukaratirwa, S., 2018, 'The political ecology of stakeholder-driven climate change adaptation: Case study from Ntalale ward, Gwanda district, in Zimbabwe', Jàmbá: Journal of Disaster Risk Studies 10(1), a419. https://doi.org/ 10.4102/jamba.v10i1.419

Meredith, J., Robinson, J., Walker, S. \& Wydick, B., 2013, 'Keeping the doctor away: Experimental evidence on investment in preventative health products', Journal of Development Economics 105, 196-210. https://doi.org/10.1016/j.jdeveco.2013. 08.003

Mobarak, M.A., Dwivedi, P., Robert, B., Hildemann, L. \& Miller, G., 2012, 'Low demand for nontraditional cookstove technologies', Proceedings of the National Academy of Science 109(27), 10815-10820. https://doi.org/10.1073/ pnas.1115571109

Ngondjeb, Y., 2013, 'Agriculture and climate change in Cameroon: An assessment of impacts and adaptation options', African Journal of Science, Technology, impacts and adaptation options', African Journal of Science, Technology, Innovation
3.782151

Ngwa, K., Mbue, N., Balgah, R. \& Ruby, T., 2015, 'Natural disasters, vulnerability and livelihood security in rural Cameroon', International Review of Basic and Applied Sciences 3(9), 108-121.

Ntungwe, E., 2015, Flood-hit Cameroon to demolish low-lying urban homes, viewed 06 September 2017, from http://www. businessinsider.com/r-flood-hit-cameroon06 September 2017, from http://www.businessin
to-demolish-low-lying-urban-homes-2015-6.

OECD, 2016, Mitigating droughts and floods in agriculture, Paris, OECD Publishing.

Ozger, M., 2017, 'Assessment of flood damage behaviour in connection with largescale climate indices', Journal of Flood Risk Management 10, 79-86. https://doi. org/10.1111/jfr3.12158

Serre, D., Barroca, B., Balsells, M. \& Becue, V., 2016, 'Contributing to urban resilience to floods with neighbourhood design: The case of AmSandtorkai/Dalmannkai in Hamburg', Journal of Flood Risk Management. https://doi.org/10.1111/ jfr3.12253

Speight, L.J., Hall, J.W. \& Kilsby, C.G., 2017, 'A multi-scale framework for flood risk analysis at spatially distributed locations', Journal of Flood Risk Management 10, 124-137. https://doi.org/10.1111/jfr3.12175

United Nations International Strategy for Disaster Reduction (UNISDR), 2015, Sendai framework for disaster risk reduction 2015-2030, viewed 28 February 2018, from http://www.unisdr.org/files/43291_sendaiframeworkfordrren.pdf. 
Wachinger, G., Renn, O., Begg, C. \& Kuhlicke, C., 2013, 'The risk perception paradox-implications for governance and communication of natural hazards', Society Risk Analysis 33(6), 1049-1065. https://doi.org/10.1111/j.1539-6924. 2012.01942.x

World Bank Report, 2014a, Managing disaster risks for resilient development, viewed 10 September 2015, from http://www.worldbank.org/en/results/2013/04/12/ managing-disaster-risks-resilient-development.

World Bank Report, 2014b, Cameroon socio-economic statistic, viewed 23 October 2015 from http://www.stwr.org/globalization/world-bank-poverty-figures-what-do-theymean.html.
World Disaster Report, 2015, World disasters report: Focus on local actors, the key to humanitarian effectiveness, [EN/AR] IFRC, viewed 22 May 2017, from http:// humanitarian effectiveness, [EN/AR] IFRC, viewed 22 .
reliefweb.int/report/world/world-disasters-report-2015.

Yengoh, G., 2012, 'Climate and food production: Understanding vulnerability from pasttrends in Africa's Sudan-Sahel', Sustainability 5, 52-57. https://doi.org/ $10.3390 /$ su5010052

Zeller, M., Sharma, M., Henry, C. \& Lapenu, C., 2006, 'An operational method for assessing outreach performance of development policies and projects. Results of case studies in Africa, Asia and Latin America', World Development 34(3), 446-464. https://doi.org/10.1016/j.worlddev.2005.07.020 